\title{
Short-term effects of forced eccentric contractions on collagen synthesis and degradation in rat skeletal muscle
}

Citation for published version (APA):

Koskinen, S. O., Ahtikoski, A. M., Komulainen, J., Hesselink, M. K. C., Bemelman, W. A., \& Takala, T. E. S. (2002). Short-term effects of forced eccentric contractions on collagen synthesis and degradation in rat skeletal muscle. Pflugers Archiv-European Journal of Physiology, 444(1-2), 59-72. https://doi.org/10.1007/s00424-002-0792-2

Document status and date:

Published: 01/01/2002

DOI:

10.1007/s00424-002-0792-2

Document Version:

Publisher's PDF, also known as Version of record

Document license:

Taverne

Please check the document version of this publication:

- A submitted manuscript is the version of the article upon submission and before peer-review. There can be important differences between the submitted version and the official published version of record.

People interested in the research are advised to contact the author for the final version of the publication, or visit the DOI to the publisher's website.

- The final author version and the galley proof are versions of the publication after peer review.

- The final published version features the final layout of the paper including the volume, issue and page numbers.

Link to publication

\footnotetext{
General rights rights.

- You may freely distribute the URL identifying the publication in the public portal. please follow below link for the End User Agreement:

www.umlib.nl/taverne-license

Take down policy

If you believe that this document breaches copyright please contact us at:

repository@maastrichtuniversity.nl

providing details and we will investigate your claim.
}

Copyright and moral rights for the publications made accessible in the public portal are retained by the authors and/or other copyright owners and it is a condition of accessing publications that users recognise and abide by the legal requirements associated with these

- Users may download and print one copy of any publication from the public portal for the purpose of private study or research.

- You may not further distribute the material or use it for any profit-making activity or commercial gain

If the publication is distributed under the terms of Article 25fa of the Dutch Copyright Act, indicated by the "Taverne" license above, 


\begin{abstract}
Acute downhill running has been shown to activate matrix metalloproteinase- (MMP-) 2 and to change type IV collagen concentration in some muscle types. In order to study the influence of more intense exercise on total collagen and type IV collagen concentrations, molecules regulating their synthesis and degradation were investigated after forced lengthening contractions in rat skeletal muscle. Tibialis anterior (TA) muscle of 24 male Wistar rats was subjected to 240 forced lengthening contractions. TA muscle was excised at consecutive time points ( 0 and $6 \mathrm{~h}, 2,4$, and 7 days) after stimulation. With immunohistochemistry, types I, III and IV collagen were located in the swollen, necrotic and regenerated fibres in a similar manner as in intact undamaged skeletal muscle fibre. An increase in the activity of prolyl 4-hydroxylase was indicative of an overall elevated collagen biosynthesis. No change was demonstrated in total collagen concentration, whereas type IV collagen concentration increased after exercise. MMP-2 and MMP-9, which are the proteins that degrade type IV collagen, elevated after exercise. In conclusion, the increase in type IV collagen concentration seems to be the result of an increase in both the synthesis and activation of degrading enzymes and their inhibitors during recovery after forced lengthening contractions.
\end{abstract}

\section{S.O.A. Koskinen ( $)$ A.M. Ahtikoski · T.E.S. Takala \\ Neuromuscular Research Center, \\ Department of Biology of Physical Activity, \\ University of Jyväskylä, PO Box 35, 40351 Jyväskylä, Finland \\ e-mail: koskinen@maila.jyu.fi \\ Tel.: +358-14-2602074, Fax: +358-14-2602071 \\ T.E.S. Takala \\ Department of Sports Medicine, Deaconess Institute of Oulu, 90100 Oulu, Finland}

\section{J. Komulainen \\ LIKES-Research Center for Sport and Health Sciences, \\ 40700 Jyväskylä, Finland}

M.K.C. Hesselink · M.R. Drost

Department of Movement Sciences

and Department of Biomedical Technology, Maastricht University, PB 616, 6200 MD Maastricht, The Netherlands
Keywords Collagen degradation - Collagen synthesis . Matrix metalloproteinase $\cdot$ Rat $\cdot$ Skeletal muscle damage · Tissue inhibitor of metalloproteinase

\section{Introduction}

The extracellular matrix provides mechanical support for skeletal muscle and plays an important role in force transmission. The predominant compounds of the extracellular matrix in skeletal muscle are fibrillar types I and III collagen, whereas non-fibrillar type IV collagen, which is located in basement membranes, comprises only a small part of the total extracellular matrix [53]. The rate of total collagen biosynthesis has previously been estimated by measuring the activity of prolyl 4-hydroxylase [37, 45, 47, 48], the post-translational modifier enzyme of collagen [22]. In addition to increased collagen synthesis, e.g. by mechanical tissue loading, a concomitant accelerated degradation indicates increased collagen turnover, which is important for maintaining the balance between intracellular and extracellular matrix compounds in the tissue. With regard to collagen degradation, its triple-helical structure is resistant to general proteolysis and thus requires specific proteases to be degraded. It is known that the degradation of collagens is initiated by the family of zinc-dependent proteases called matrix metalloproteinases (MMPs) [39], which are secreted as inactive proenzymes, and their proteolytic activity is regulated by enzymatic cleavage of the propeptide and inhibited by tissue inhibitors of matrix metalloproteinases (TIMPs) [10]. Mechanical stress causes changes in the protein expression of connective tissue cells, and thus a remodelling of the extracellular matrix to meet requirements of the changes in mechanical load [5]. This has been demonstrated, at least partly, in rat skeletal muscle after downhill running, where type IV collagen turnover increased in some muscle types [28]. In the present study strenuous mechanical stress was induced by forced lengthening contractions on rat tibialis anterior (TA) muscle in order to investigate the influence 
of damaging exercise on collagen turnover in skeletal muscle. It has previously been described that this experimental model actually does cause muscle damage and the sequence of the myofibre disruption has been described by light microscopy examination of immunohistochemical staining for desmin, dystrophin, actin and fibronectin [27]. The purpose of this study was thus to investigate the expression of type I, III and IV collagens and proteins regulating their degradation in damaged rat skeletal muscle. Furthermore, in order to combine results from the turnover of extracellular matrix with collagen structure in muscle, the muscle specimens after forced lengthening contractions were stained with specific antibodies for types I, III and IV collagen.

\section{Materials and methods}

Animals

Twelve-week-old male Wistar rats $(n=24)$ were used in this study. Animals were housed individually in cages with free access to pelleted chow and tap water under constant temperature $\left(22^{\circ} \mathrm{C}\right)$, humidity (40\%) and light-dark (light between 7:00 a.m. and 7:00 p.m.) conditions. Treatment of the animals was in accordance with the European Convention for the Protection of the Vertebrate Animals Used for Experimental and Other Scientific Purposes. The Institutional Animal Care and Use Committee of the Maastricht University approved the experiment.

\section{Forced lengthening}

Animals were anaesthetized with pentobarbital sodium (Narcovet $1.0 \mathrm{ml} / \mathrm{kg}$ body mass) administered intraperitoneally after shortterm $(<20 \mathrm{~s}) \mathrm{CO}_{2}$ sedation, and the left TA muscle was subsequently unilaterally subjected to 240 forced lengthening contractions in 4 bouts of 60 contractions (one contraction every $3 \mathrm{~s}$ ) interspaced with a 5-min recovery period. Fused tetanic contractions were induced by electrical stimulation of the exposed common peroneal nerve (typically with $\cong 150 \mathrm{~Hz}$ and $\cong 3 \mathrm{~V}$ ) for $300 \mathrm{~ms}$ via a stainless steel electrode. Lengthening of the contracted TA muscle was performed by dorsiflexion of the foot at the ankle joint (rotation from $80^{\circ}$ to $130^{\circ}$ ) with a rotational velocity of $500 / \mathrm{s}$. After exercise, the electrode was carefully removed. The contralateral leg was used as a non-exercised control. The exercise protocol, including the effect of sham surgery, is described in detail in the study by Hesselink et al [16].

\section{Tissue preparation}

At consecutive time points ( 0 and 6 h, 2, 4 and 7 days) after the forced lengthening, the TA muscles were rapidly excised. Tissue for light microscopy were cut from the mid-belly regions of TA muscle, mounted on a specimen holder with Optical Cutting Temperature (OCT) compound (Miles, Elkhart, Ind., USA) and frozen in isopentane cooled in liquid nitrogen. Proximal and distal parts of TA muscles were frozen in liquid nitrogen. All samples were stored at $-70^{\circ} \mathrm{C}$ until further analysis.

For total RNA isolation, the frozen samples from distal part of TA muscles were weighed and homogenized with an Ultra-Turrax homogenizer in denaturing solution (Gibco BRL TRIZOL Reagent, $1 \mathrm{ml}$ per $50-100 \mathrm{mg}$ ). The steps of isolation were performed according to the manufacturer's instructions. The concentration and purity of each sample were evaluated spectrophotometrically using absorbencies at 260 and $280 \mathrm{~nm}$.

For enzyme activity measurements, concentrations of type IV collagen and total collagen and quantification of type I and type
III collagen ratios, the frozen samples from proximal part of TA muscles were homogenized with an Ultra-Turrax homogenizer in two 7 -s bursts at $4^{\circ} \mathrm{C}$ in a cold solution containing $0.2 \mathrm{M} \mathrm{NaCl}$, $0.1 \%$ (w/v) Triton X-100, 0.1 M glycine, and 0.02 M TRIS-HCl, $\mathrm{pH}$ adjusted to 7.4. The homogenates $(6-10 \% \mathrm{w} / \mathrm{v})$ were centrifuged and the supernatants were taken for assay of the enzyme activities. Pellets were divided for determination of the type IV collagen concentration and quantification of type I and type III collagen ratios. For the analysis of type IV collagen, the muscles pellets were suspended in $0.2 \mathrm{M}$ ammonium bicarbonate and digested first with collagenase (Worthington Biochemical, Lakewood, N.J., USA) for $20 \mathrm{~h}$ at room temperature, then with trypsin (Sigma, St. Louis, Mo., USA) for a further $20 \mathrm{~h}$ at room temperature [20]. The enzyme reaction was stopped by trypsin inhibitor (Sigma) [20]. The samples were centrifuged and the supernatants were collected for type IV collagen concentration measurement. The other half of the muscle pellets, saved for the quantification of type I and type III collagen ratios, was resuspended in $2 \%$ SDS in order to remove non-collagen proteins. SDS extraction was repeated four times. The pellets were washed three times with PBS and then twice with acetone. The remaining residues were suspended in $1 \mathrm{ml}$ of $70 \%$ formic acid and digested by adding $5 \mu \mathrm{g}$ cyanogen bromide per $1 \mathrm{mg}$ muscle wet weight. Digestion was accomplished at $35^{\circ} \mathrm{C}$ for $4 \mathrm{~h}$. The reaction was stopped and cyanogen bromide was removed by diluting with several volumes of distilled water and evaporation [31]. The remaining residues were resuspended in water and divided up into samples for measuring the hydroxyproline concentration and cyanogen bromide peptide electrophoresis. Types I (rat tail, C8897, Sigma) and III (recombinant human type III collagen), which were used as standards in cyanogen bromide electrophoresis, were treated in the same way as described above.

\section{Immunohistochemistry}

Serial transverse sections $(10 \mu \mathrm{m})$ were cut in a cryostat at $-20^{\circ} \mathrm{C}$. Sections were stained with hematoxylin and eosin (HE) to investigate the histopathological changes. Rabbit anti-human type IV collagen (dilution 1:500, Chemicon, Temecula, Calif., USA), rabbit anti-rat type I and III collagen (dilution 1:100, Sanbio, The Netherlands), mouse monoclonal anti-dystrophin (1: 500, days 2, Novocastra, UK), and rabbit polyclonal anti-fibronectin (1:500) antibodies were used in the immunohistochemical staining. The transverse sections were incubated with appropriate dilutions of the primary antibody overnight at $+4^{\circ} \mathrm{C}$. After washing with TRIS-buffered saline (TBS, $\mathrm{pH}=7.5$ ) the bound primary antibodies were visualized by avidin-biotin peroxidase kits (Vector Laboratories, Burlingame, Calif., USA) for mouse (Vectastain PK-4002) or for rabbit (Vectastain PK-4001) using diaminobenzidine (Sigma) as a chromogen. The sections were contrasted with hematoxylin staining.

Northern and slot blot analysis

For Northern blotting, $10 \mathrm{mg}$ total RNA was separated in $1 \%$ agarose-formaldehyde gel under denaturating conditions and transferred onto a nylon membrane (Schleicher and Schuell, Dassel, Germany) by a 3-h downward capillary transfer. For slot blots, $15 \mu \mathrm{g}$ of each total RNA sample was applied to a nylon membrane by using a vacuum filtration manifold (Minifold II Manifold, Scheicher and Schuell). The complementary DNA (cDNA) probes were labelled by commercial random primer labelling kit (Amersham Pharmacia Biotech, Uppsala, Sweden) with [ $\alpha-32 \mathrm{P}]-\mathrm{dCTP}$ according to the manufacturer's manual. The membranes were prehybridized for $2-3 \mathrm{~h}$ at $42^{\circ} \mathrm{C}$, after which the radioactive probe was added, and then hybridized for $24 \mathrm{~h}$ at $42^{\circ} \mathrm{C}$. After hybridization, the membranes were washed and exposed to Kodak X-omat or Agfa Curix film at $-70^{\circ} \mathrm{C}$. For the quantification and a comparison of the relative amounts of mRNA, signal intensities of the bands were scanned by densitometry (Personal Densitometry SI, Molecular Dynamics, Sunnyvale, Calif., USA). The results are 
given as values of integrated optical density. Equal amounts of RNA in each slot or lane were confirmed using a 24-mer oligonucleotide for $18 \mathrm{~S}$ ribosomal RNA [4]. The membranes were hybridized with MMP-2, MMP-9, TIMP-1, TIMP-2, $\alpha 1$ (IV) collagen, pro $\alpha 1$ (III) collagen, pro $\alpha 1$ (I) collagen, lysyl oxidase, $\alpha$-subunit of prolyl 4-hydroxylase and $\beta$-subunit of prolyl 4-hydroxylase (more detail information see references $[12,28]$ ).

\section{Prolyl 4-hydroxylase activity assay}

The assay for prolyl 4-hydroxylase activity was based on the measurement of labelled hydroxyproline formed from peptide-bound prolyl residues of unhydroxylated, labelled protocollagen substrate [23]. Enzymatic activity was assayed in a final volume of $1 \mathrm{ml}$ containing $70 \mu \mathrm{l}$ supernatants from centrifuged muscle homogenates, $7 \mu \mathrm{l}$ of $0.5 \mathrm{mM}$ dithiothreitol, $7 \mu \mathrm{l}$ of $0.1 \%(\mathrm{w} / \mathrm{v})$ soybean trypsin inhibitor solutions, 50,000 dpm proline-labelled protocollagen-C ${ }^{14}, 0.08 \mathrm{mM} \mathrm{FeSO}_{4}, 0.5 \mathrm{mM} \alpha$-ketoglutarate, $2 \mathrm{mM}$ ascorbic acid, $0.002 \%(\mathrm{w} / \mathrm{v})$ BSA (bovine albumin serum), and $50 \mathrm{mM}$ Tris- $\mathrm{HCl}$ buffer, $\mathrm{pH}$ 7.8. The test tubes were incubated for $1 \mathrm{~h}$ at $37^{\circ} \mathrm{C}$, and the reaction was stopped by transferring the tubes to iced water and the addition of $1 \mathrm{ml}$ concentrated $\mathrm{HCl}$. The samples were hydrolysed overnight at $120^{\circ} \mathrm{C}$. After evaporating the

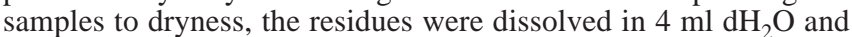
the total ${ }^{14} \mathrm{C}$-contents were measured with a liquid scintillation counter. Hydroxyproline- ${ }^{14} \mathrm{C}$ was assayed by oxidation to pyrrole${ }^{14} \mathrm{C}$ as described previously [18]. Pyrrole- ${ }^{14} \mathrm{C}$ contents were measured with a liquid scintillation counter. The prolyl 4-hydroxylase activities are expressed as $\mathrm{dpm} \cdot \mathrm{h}^{-1} \cdot \mathrm{g}^{-1}$ protein.

\section{Gelatin zymography}

Gelatinase activities of proMMP-2 and the active form of MMP-2 were quantified with zymography as described by Kleiner and Stetler-Stevenson [26]. SDS polyacrylamide gels (11\%) containing $1 \mathrm{mg} / \mathrm{ml}$ gelatin were overlaid with $4 \%$ stacking gels. Supernatants from centrifuged muscle homogenates were mixed with $1: 1$ volume of sample buffer without reducing agent or heat. Gels were incubated in the washing solutions in order to remove SDS from the gels. Gelatinase activity was revealed by negative staining with Coomassie brilliant blue. Purified proMMP-2 (Diabor, Oulu, Finland) was used to identify enzyme activity. The degree of digestion was quantified by densitometry (Personal Densitometry SI, Molecular Dynamics, Sunnyvale, Calif., USA). The values of integrated optical density were used for further analysis.

\section{Collagen zymography}

ProMMP-9 and the active form of MMP-9 were analysed with collagen zymography as described by Gogly et al. [9]. SDS polyacrylamide gels $(10 \%)$ containing $0.8 \mathrm{mg} / \mathrm{ml}$ collagen (Worthington Biochemical) were overlaid with $4 \%$ stacking gels. Samples, gel electrophoresis, removal of SDS, activation of collagenase activity and the staining of gels were performed as described in the section on gelatin zymography. Purified proMMP-9 (Diabor, Oulu, Finland) was used for identification of enzyme activity.

\section{Reverse gelatin zymography}

TIMP-1 and TIMP-2 were analysed with reverse zymography as described by Oliver et al. [40]. SDS polyacrylamide gels (12\%) containing $2 \mathrm{mg} / \mathrm{ml}$ gelatin and $180 \mathrm{ng} / \mathrm{ml}$ proMMP-2 (Diabor, Oulu, Finland) were prepared. A standard stacking gel of $4 \%$ was used. Supernatants from centrifuged muscle homogenates were mixed with 1:5 volume of sample buffer without reducing agent or heat. The electrophoresis was carried out until the dye front had reached the bottom of the gel. Gels were incubated in the washing solutions in order to remove SDS from gels. Gels were stained with Coomassie brilliant blue. MMP-2 inhibitory activity of TIMPs resulted in the presence of dark blue bands on a clear background. Purified TIMP-1 and TIMP-2 (Diabor, Oulu, Finland) were run as standards.

\section{Type IV collagen concentration}

Type IV collagen content was measured with radioimmunoassay as a concentration of the $7 \mathrm{~S}$ domain of type IV collagen [43]. Briefly, in the standard inhibition assay, antibody against the $7 \mathrm{~S}$ domain, capable of binding $40 \%$ of labelled $7 \mathrm{~S}$ antigen, was incubated for $2 \mathrm{~h}$ at $37^{\circ} \mathrm{C}$ together with non-labelled $7 \mathrm{~S}$ antigen (standard) or samples (supernatants from collagenase and trypsin-digested muscle pellet) and ${ }^{125}$ I-labelled $7 \mathrm{~S}$ antigen. Free and bound antigens were separated by precipitation with goat antiserum to rabbit immunoglobulin G (Fitzgerald Industries, Concord, Mass., USA).

Hydroxyproline concentration

A part of cyanogen-bromide-digested muscle pellets were hydrolysed in $6 \mathrm{M} \mathrm{HCl}$ overnight at $110^{\circ} \mathrm{C}$, dried and dissolved in distilled water. The hydroxyproline concentration was measured as described by Creemers et al. [6]. Briefly, samples were incubated with chloramin-T reagent in duplicate in 96-well microtitreplate (15 min, room temperature). Subsequently, 4-dimethylamino benzaldehyde reagent was added $\left(20 \mathrm{~min}, 60^{\circ} \mathrm{C}\right)$, and, following cooling of the plate, extinction was read at $565 \mathrm{~nm}$ by a microtitre plate reader (iEMS Reader MF, Labsystems, Finland).

\section{Cyanogen bromide peptide electrophoresis}

Supernatants from cyanogen-bromide-digested muscle pellets and types I and III collagen were dissolved to a final hydroxyproline concentration of $1 \mu \mathrm{g} / \mu \mathrm{l}$ in sample buffer by heat at $95^{\circ} \mathrm{C}$ for $4 \mathrm{~min}$. Samples were loaded on 8-20\% linear gradient SDS-polyacrylamide gels (29:1 acrylamide to bis- $N, N^{\prime}$-methylenebisacrylamide ratio) with $4 \%$ stacking gels and electrophoresed overnight at $70 \mathrm{~V}$ [34]. Gels were fixed overnight, stained with Coomassie brilliant blue and destained. Types I and III collagen standards were included with each gel so that a standard curve of collagen versus staining density could be constructed. Quantification of the relative amounts of types I and III collagen was based on the presence of the peptides $\alpha 1$ (I)CB8 and the co-migrating peptides $\alpha 1$ (III)CB5 plus $\alpha 1$ (III)CB9 [13, 31].

\section{Statistics}

Statistical evaluation of the results was performed by the use of non-parametric Wilcoxon signed-rank test for two related samples. Statistical comparisons were made between the contralateral TA and stimulated TA. Variability of the data is expressed as means \pm SEM. Differences were considered statistically significant at $P<0.05$. When there were only four samples per observation point and all four samples were higher or lower than the contralateral ones $(P=0.068)$, the paired-samples $t$-test was performed to evaluate statistical significance.

\section{Results}

Localization of types I, III and IV collagen in damaged skeletal muscle fibres

Forced lengthening contractions did not in general alter immunostaining for types I, III and IV collagen immedi- 

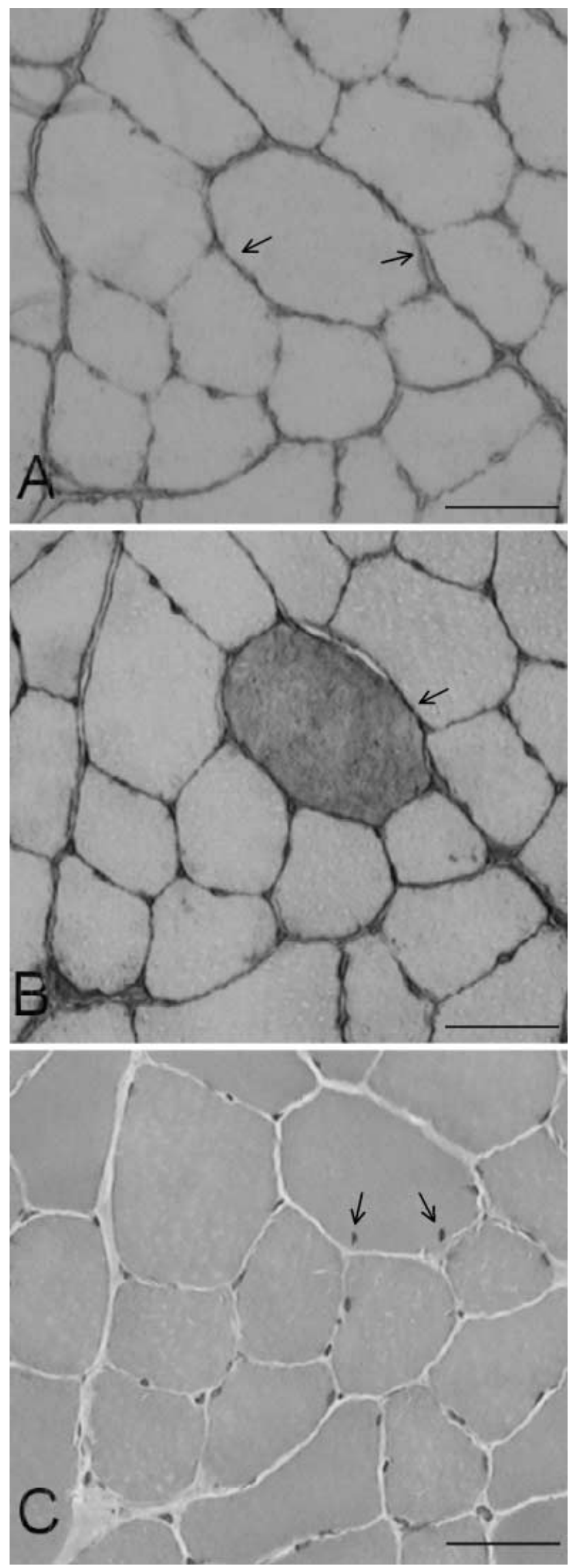

Table 1 Prolyl 4-hydroxylase activity in tibialis anterior (TA) muscle after forced lengthening contractions. The activities are expressed as $\mathrm{dpm} \cdot \mathrm{h}^{-1} \cdot \mathrm{g}^{-1}$ protein. Values are means \pm SEM. Significance $P$ as a result of nonparametric Wilcoxon signed-rank test for two related samples

\begin{tabular}{llll}
\hline Time & Contralateral TA & Exercised TA & $P(n)$ \\
\hline $0 \mathrm{~h}$ & $9800 \pm 900$ & $10000 \pm 900$ & $0.893(5)$ \\
$6 \mathrm{~h}$ & $14400 \pm 700$ & $10200 \pm 500^{*}$ & $0.043(5)$ \\
2 days & $17000 \pm 800$ & $24000 \pm 1000^{\#}$ & $0.068(4)$ \\
4 days & $17500 \pm 1700$ & $37500 \pm 3700^{*}$ & $0.043(5)$ \\
7 days & $12100 \pm 800$ & $51600 \pm 12400^{\#}$ & $0.068(4)$ \\
\hline
\end{tabular}

${ }^{\#} P<0.05$ the paired-samples, $t$-test, ${ }^{*} P<0.05$

ately after loading, but a few muscle fibres were already swollen at this time point (data not shown). When studied $6 \mathrm{~h}$ after lengthening contractions, immunohistochemical staining of type IV collagen (Fig. 1A) indicated continuous intact staining in the basement membrane around muscle fibre, whereas in some fibres fibronectin (Fig. 1B) was located intracellularly and in the same cells nuclei were turned towards the centre of muscle fibre (Fig. 1C). Two days post exercise, type IV collagen staining was still visible in the contour of basement membranes of skeletal muscle fibres (Fig. 2A), from which several cells were dystrophin-negative (Fig. 2B), intracellularly fibronectin positive (Fig. 2C) and inflammatory cells infiltrated (Fig. 2D). Four days following the forced lengthening contractions some necrotic areas were identified. In these areas the contour of basement membranes of skeletal muscle fibres were still visible in the immunohistochemical stainings for type IV collagen (Fig. 3A). Types I (data not shown) and III (Fig. 3B) collagen showed endomysial staining around necrotic fibres at this time point (Fig. 3C). Seven days after forced lengthening contractions, type IV collagen staining was observed in the basement membranes of small central nucleated cells (Fig. 4A) and a thin layer of endomysial staining for type I (data not shown) and III (Fig. 4B) collagen was seen, at this time point, around these regenerating fibres (Fig. 4C).

\section{Collagen synthesis and degradation}

Prolyl 4-hydroxylase activity, as an indicator of collagen biosynthesis, was higher in exercised TA compared to contralateral TA 2, 4, and 7 days after forced lengthening contractions. However, at $6 \mathrm{~h}$ postexercise the activity of prolyl 4-hydroxylase was in fact lower in stimulated TA than in contralateral TA (Table 1). Seven days after

Fig. 1 Type IV collagen immunohistological staining (A, arrows) of rat tibialis anterior muscle $6 \mathrm{~h}$ after forced lengthening contractions showed intact staining in the basement around muscle fibre although fibronectin (B, arrow) was located intracellularly. Abnormal location of nuclei in the damaged skeletal muscle fibre (C, arrows) observed in hematoxylin-eosin staining. Bar=50 $\mu \mathrm{m}$ 

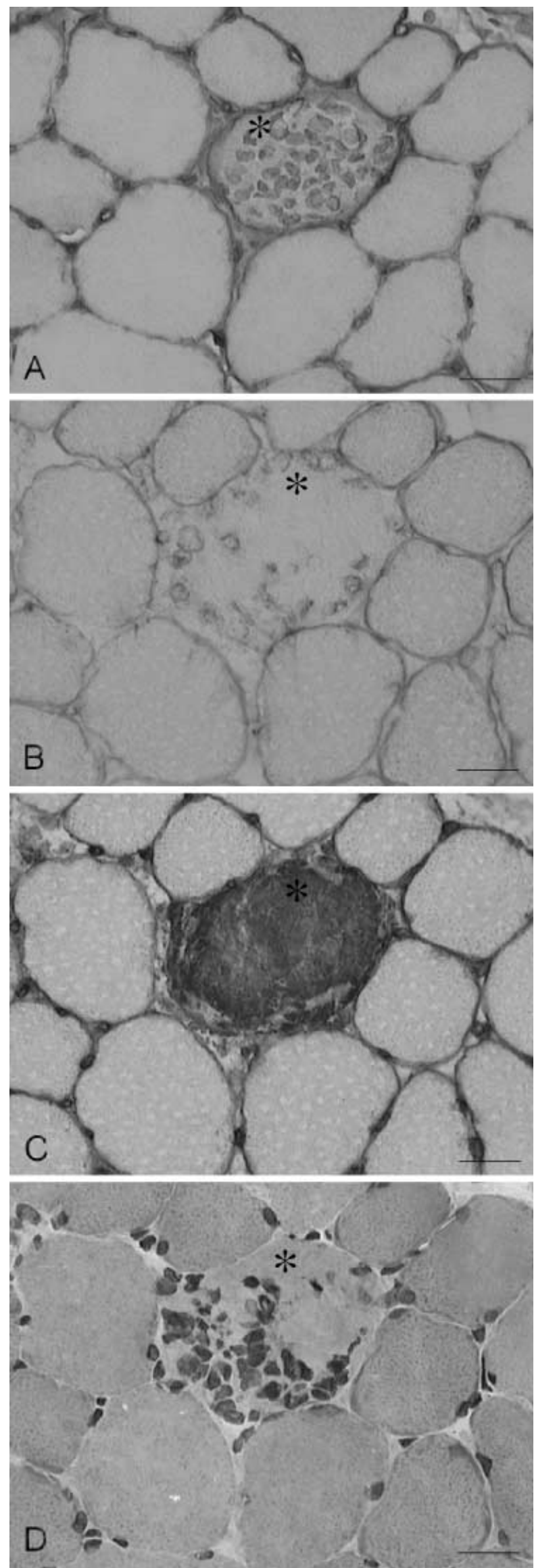
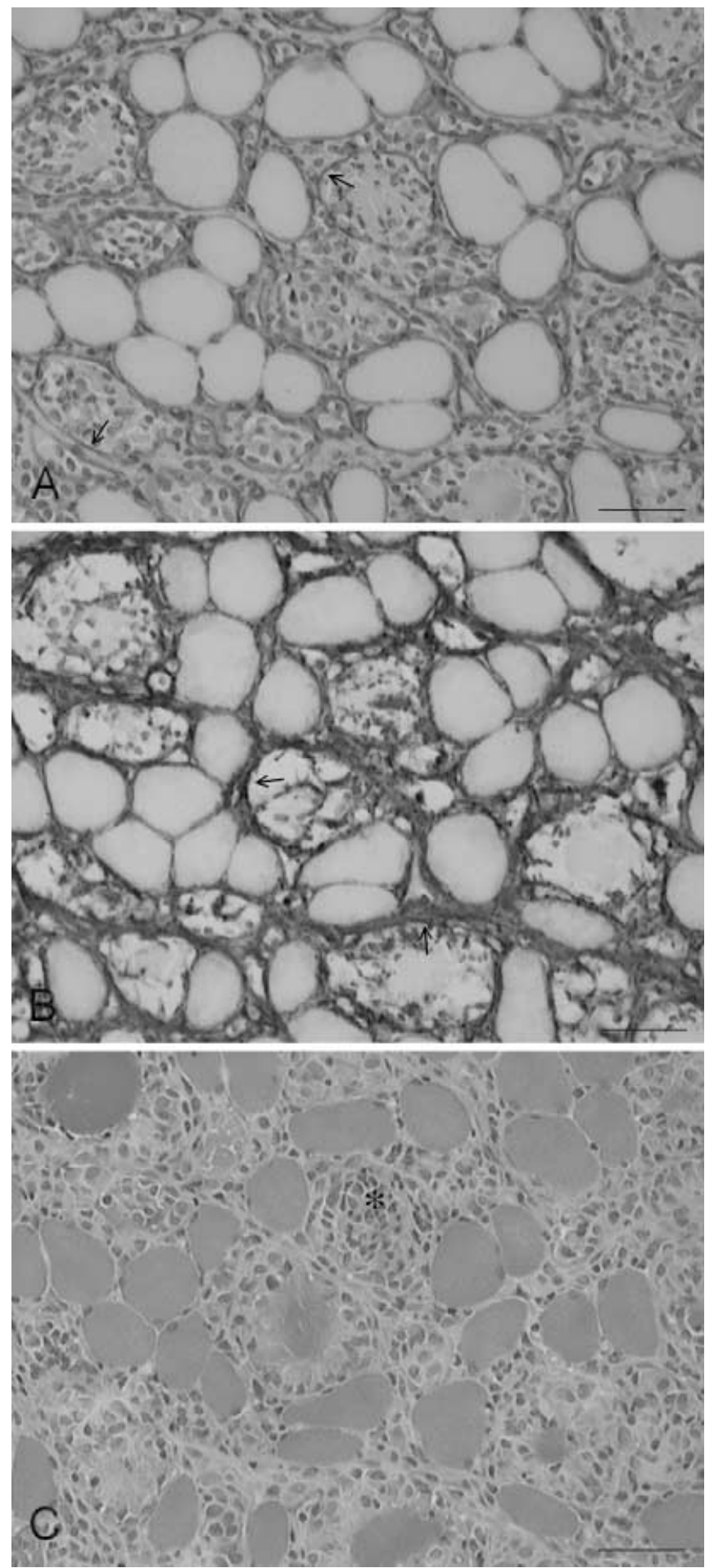

Fig. 3A-C Necrotic area of rat tibialis anterior muscle 4 days after forced lengthening contractions. The contour of basement membranes of skeletal muscle fibres were visible in the immunohistochemical stainings for type IV collagen (A, arrows). Endomysial staining for type III collagens was observed around necrotic fibres (B). Infiltration of inflammatory cells (C, asterisk, hematoxylin-eosin staining). Bar=50 $\mu \mathrm{m}$

4 Fig. 2A-D Detail picture of damaged skeletal muscle fibre (asterisk) 2 days after forced lengthening contractions. In the contour of basement membranes of skeletal muscle fibres, type IV collagen immunohistochemical staining is visible (A), while dystrophin staining is negative (B), fibronectin is located intracellularly $(\mathbf{C})$ and the fibre is infiltrated by inflammatory cells $(\mathbf{D}$, hematoxylineosin staining). Bar $=25 \mu \mathrm{m}$ 

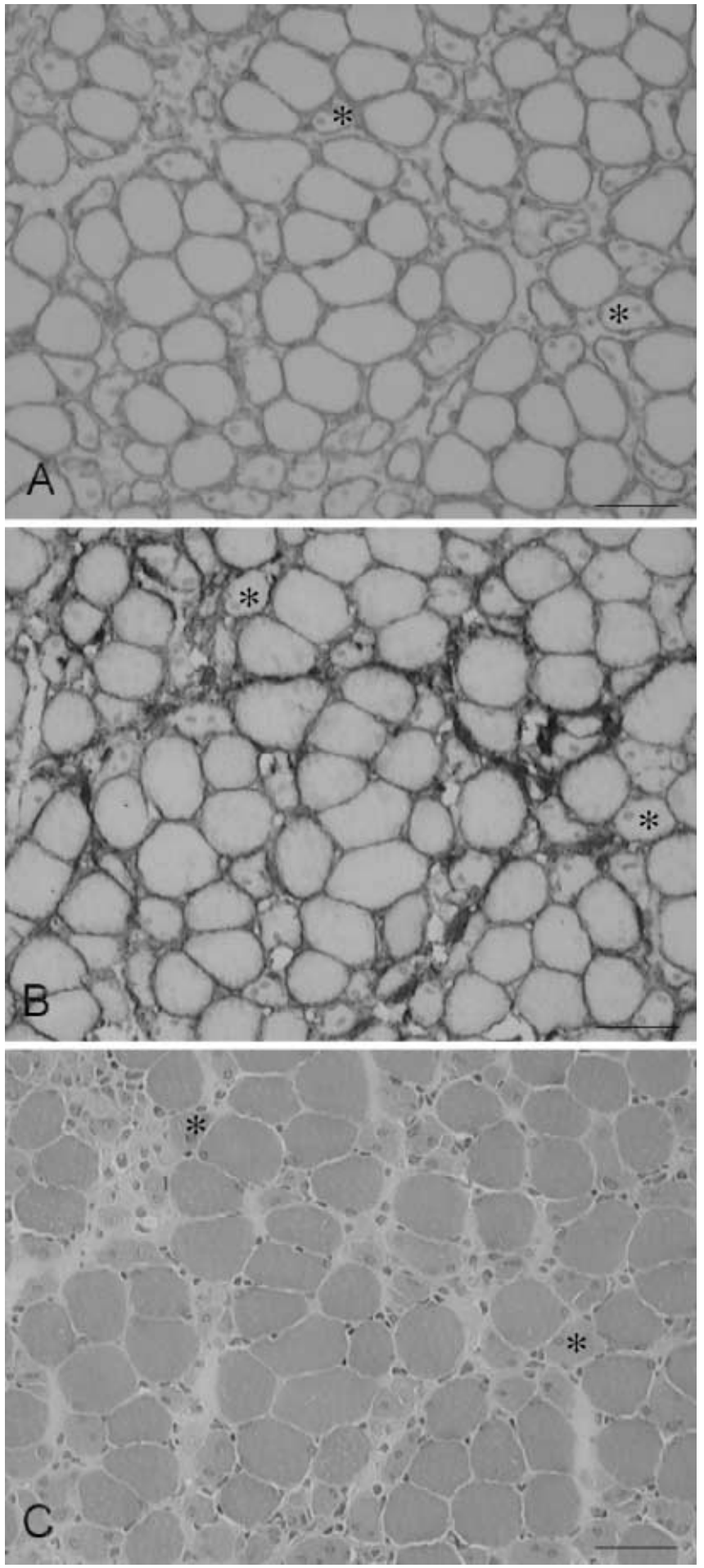

Fig. 4 Small regenerating fibres with central nuclei $(\mathbf{C}$, asterisk, hematoxylin-eosin staining), in rat tibialis anterior muscle 7 days after forced lengthening contractions. Type IV collagen staining (A) was observed in the basement membranes of small central nucleated cells. Thin layer of endomysial staining for type III (B) collagen were seen around these regenerating fibres. Bar $=50 \mu \mathrm{m}$
Table 2 Type IV collagen concentration, measured with RIA as the concentration of the $7 \mathrm{~S}$ domain of type IV collagen, in rat tibialis anterior $(T A)$ muscle after forced lengthening contractions. Concentrations are $\mathrm{ng} / \mathrm{mg}$ muscle wet weight. Values are means \pm SEM. Significance $P$ as a result of nonparametric Wilcoxon signed-rank test for two related samples

\begin{tabular}{llll}
\hline Time & Contralateral TA & Exercised TA & $P(n)$ \\
\hline $0 \mathrm{~h}$ & $237 \pm 29$ & $236 \pm 51$ & $0.715(4)$ \\
$6 \mathrm{~h}$ & $250 \pm 21$ & $254 \pm 49$ & $1.000(4)$ \\
2 days & $186 \pm 32$ & $250 \pm 38$ & $0.144(4)$ \\
4 days & $255 \pm 31$ & $392 \pm 31^{\#}$ & $0.068(4)$ \\
7 days & $235 \pm 20$ & $444 \pm 58^{*}$ & $0.043(5)$ \\
\hline
\end{tabular}

${ }^{\#} P<0.05$ the paired-samples, $t$-test, ${ }^{*} P<0.05$

Table 3 Total collagen concentration, measured as hydroxyproline concentration, in rat tibialis anterior $(T A)$ muscle after forced lengthening contractions. Concentrations are $\mu \mathrm{g} / \mathrm{mg}$ muscle wet weight. Values are means \pm SEM. Significance $P$ as a result of nonparametric Wilcoxon signed-rank test for two related samples

\begin{tabular}{llll}
\hline Time & Contralateral TA & Exercised TA & $P(n)$ \\
\hline $0 \mathrm{~h}$ & $1.02 \pm 0.17$ & $0.85 \pm 0.14$ & $0.345(5)$ \\
$6 \mathrm{~h}$ & $1.20 \pm 0.11$ & $1.15 \pm 0.14$ & $0.500(5)$ \\
2 days & $1.30 \pm 0.13$ & $1.13 \pm 0.17$ & $0.715(4)$ \\
4 days & $1.22 \pm 0.25$ & $1.20 \pm 0.49$ & $0.893(5)$ \\
7 days & $1.26 \pm 0.29$ & $1.19 \pm 0.25$ & $0.893(5)$ \\
\hline
\end{tabular}

forced lengthening contractions, as high as a 4.3-fold increase in prolyl 4-hydroxylase activity was observed. Type IV collagen concentrations in exercised TA rose in response to forced lengthening and were at 4 and 7 days significantly higher compared to contralateral TA (Table 2). The total collagen concentration (Table 3), measured as the hydroxyproline concentration, as well as the type I to III collagen ratio (data is not shown) were not different between exercised and control TA at all observation points. Gelatinolytic activity of proMMP-2 were higher in exercised TA than control TA at 2, 4 and 7 days postexercise (Fig. 5A, B), whereas the active form of MMP-2 was visible (Fig. 5A, the lowest band) in all exercised TA muscles at 4 and 7 days after forced lengthening contractions. Neither gelatinolytic activity of proMMP-9 nor the active form of MMP-9 were observed in any of the samples in gelatin zymography gels, but if soluble collagen was incorporated in gels instead of gelatin, MMP-9 could be observed (Figs. 6). Because of the low intensity of the bands in collagen zymography gels, especially in samples from contralateral TA, collagenase activities were only estimated visually. The degree of collagen digestion in the gels was divided into four categories: invisible, faint, clear and intensive (Table 4). Collagenase activities of proMMP-9 were clearly elevated in exercised TA 2 and 4 days after forced lengthening contractions compared to contralateral TA (Fig. 6A; Table 4) and the active form of MMP-9 was clearly observed in all exercised TA muscles 4 days postexercise. Pure proMMP-2 and proMMP-9 were used to identify the bands in both gelatin and collagen zymography gels 
Fig. 5 A Gelatin zymography gels were used to quantify activities of proMMP-2 and the active form of MMP-2. Time series of tibialis anterior muscle after forced lengthening contractions ( $2 \mu \mathrm{g}$ total protein per well). B Gelatinolytic activities of proMMP-2. Values are calculated relative to contralateral tibialis anterior $(T A)$. Values are means \pm SEM. ${ }^{*} P<0.05$ (nonparametric Wilcoxon signed-rank test for two related samples). If $P=0.068$, the paired-samples $t$-test was performed ( $\left.{ }^{P} P<0.05\right)$. C Pure proMMP-2 and proMMP-9 were used to identify the bands. The active form of MMP-2 is the lowest band. There were no signs of proMMP-9 gelatinolytic activity
A.

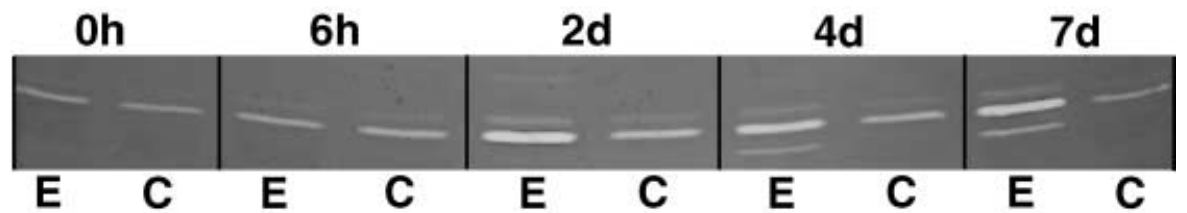

B.

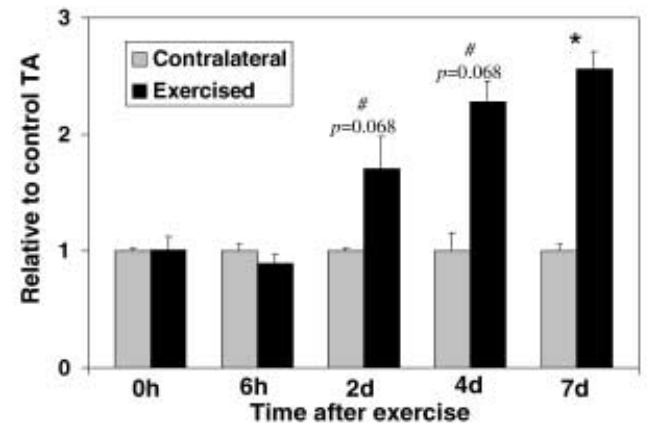

C.

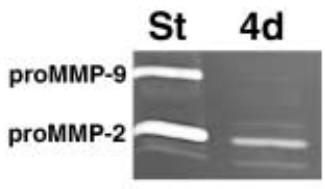

A.

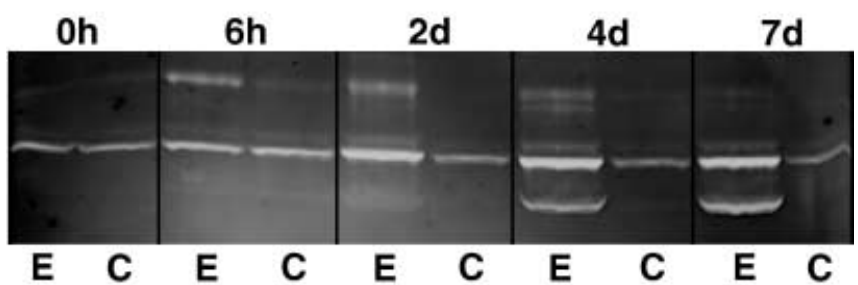

B.

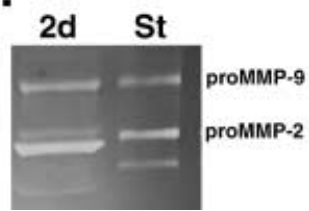

Fig. 6 A Collagen zymography gels were used to illustrate activities of proMMP-9 and the active form of MMP-9. Time series of tibialis anterior muscle after forced lengthening contractions (30 $\mu$ g total protein per well). B Pure proMMP-2 and proMMP-9 were used to identify the bands

(Figs. 5C, 6B). The MMP-2 inhibitory activity of TIMP2 was elevated in exercised TA 2, 4 and 7 days postexercise compared to contralateral TA (Fig. 7; Table 5), whereas MMP-2 inhibitory activity of TIMP-1 remained undetectable in any of the samples studied. The intensity of the bands in the gels stained with Coomassie Brilliant Blue were only estimated visually because of the intensities of the bands in the contralateral TA muscles were too low to be detected by densitometry. The intensities were divided into four categories similar to those described above for MMP-9.
Table 4 Collagenase activity of MMP-9 in rat tibialis anterior (TA) muscle after forced lengthening contractions. The intensities of the bands in the gels stained with Coomassie Brilliant were estimated visually and divided into four categories: invisible, faint, clear and intensive

\begin{tabular}{lll}
\hline Time point & Contralateral TA $(n)$ & Exercised TA $(n)$ \\
\hline $0 \mathrm{~h}$ & invisible (3), faint (2) & faint (4), clear (1) \\
$6 \mathrm{~h}$ & invisible (1), faint (3), & invisible (1), faint (1), \\
& clear (1) & clear (3) \\
2 days & invisible (4) & clear (4) \\
4 days & invisible (5) & clear (5) \\
7 days & invisible (5) & faint (4), clear (1) \\
\hline
\end{tabular}

Table 5 MMP-2-inhibitory activity of TIMP-2 in rat tibialis anterior $(T A)$ muscle after forced lengthening contractions. The intensities of the bands in the gels stained with Coomassie Brilliant were estimated visually and divided into four categories: invisible, faint, clear and intensive

\begin{tabular}{lll}
\hline Time point & Contralateral TA $(n)$ & Exercised TA $(n)$ \\
\hline $0 \mathrm{~h}$ & invisible (5) & invisible (5) \\
$6 \mathrm{~h}$ & invisible (2), faint (2) & invisible (2), faint (2) \\
$2 \mathrm{~d}$ & invisible (4) & clear (4) \\
$4 \mathrm{~d}$ & invisible (1), faint (3) & intensive (4) \\
$7 \mathrm{~d}$ & invisible (2), faint (3) & intensive (5) \\
\hline
\end{tabular}

Gene expression of specific collagen types and proteins participating in their degradation

Northern blot analysis was used to test the specificity of different cDNA probes (Fig. 8), whereas slot blot analysis was used to quantify amount of specific mRNA per $15 \mu \mathrm{g}$ of total RNA (Fig. 9). mRNA results were calculated relative to contralateral TA. The yield of total RNA per muscle wet weight increased 3.4- and 2.3-fold in exercised TA 4 and 7 days after forced lengthening contractions, respectively, compared to contralateral TA 


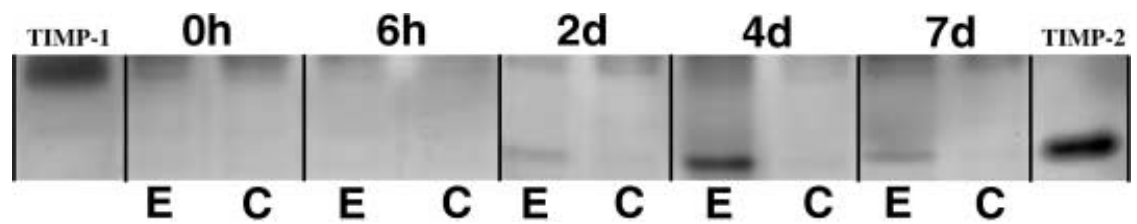

Fig. 7 Reverse gelatin zymography gels were used to quantify the MMP-2-inhibitory activities of TIMP-1 and TIMP-2. Time series of tibialis anterior muscle after forced lengthening contractions
(50 $\mu \mathrm{g}$ total protein per well). Pure TIMP-1 and TIMP-2 were used to identify the bands. TIMP-1 was below the detection limit
Fig. 8 Northern blot autoradiographs. Ten micrograms of total RNA in each lane was electrophoresed, transferred to a nylon membrane, and hybridized with specific probes, which were: $\alpha 1(\mathrm{IV})$ collagen (Type IV), pro $\alpha 1(\mathrm{I})$ collagen (Type I), proo1(III) collagen (Type III), $\alpha$-subunit of prolyl 4-hydroxylase $(\alpha P 4 H), \beta$-subunits of prolyl 4-hydroxylase $(\beta P 4 H)$, lysyl oxidase $(L O)$, matrix metalloproteinase-2 $(M M P-2)$, MMP-9, tissue inhibitor of metalloproteinase-1 (TIMP-1), TIMP-2. Equal amounts of RNA in each lane were confirmed by $18 \mathrm{~S}$ rRNA (S18) signals

\section{Oh \\ $6 h$ \\ 2d \\ 4d 7d \\ C E C E C E C E C E}

Type I

Type III

Type IV

$\alpha \mathbf{P} 4 \mathbf{H}$

$\beta \mathrm{P} 4 \mathrm{H}$

LO

MMP-2

MMP-9

TIMP-1

TIMP-2

S18
(Fig. 10). mRNA levels for fibrillar types I and III collagen showed a relatively greater increase than mRNA level for basement membrane type IV collagen (Fig. 9A, B, C). Both mRNA levels of types I and III collagen started to increase 2 days after forced lengthening contractions and were more pronounced 4 days after forced lengthening contractions and remained elevated 7 days postexercise, whereas the mRNA level for type IV collagen peaked numerically 2 and 7 days postexercise. The steady-state mRNA level of the prolyl 4-hydroxylase 
Fig. 9A-J Amounts of specific mRNAs (per $15 \mu \mathrm{g}$ total RNA) relative to contralateral TA quantified from slot blots.

A Pro $\alpha 1$ (I) collagen,

B pro $\alpha 1$ (III) collagen,

C $\alpha 1$ (IV) collagen, D $\alpha$-subunit of prolyl 4-hydroxylase $(\alpha \mathrm{P} 4 \mathrm{H}), \mathbf{E} \beta$-subunits of prolyl 4-hydroxylase $(\beta \mathrm{P} 4 \mathrm{H}), \mathbf{F}$ lysyl oxidase, G MMP-2, H MMP-9, I TIMP-1, and J TIMP-2. Values are means \pm SEM. ${ }^{*} P<0.05$ (nonparametric Wilcoxon signed-rank test for two related samples). If $P=0.068$, the paired-samples $t$-test was performed ( ${ }^{P} P<0.05$ )
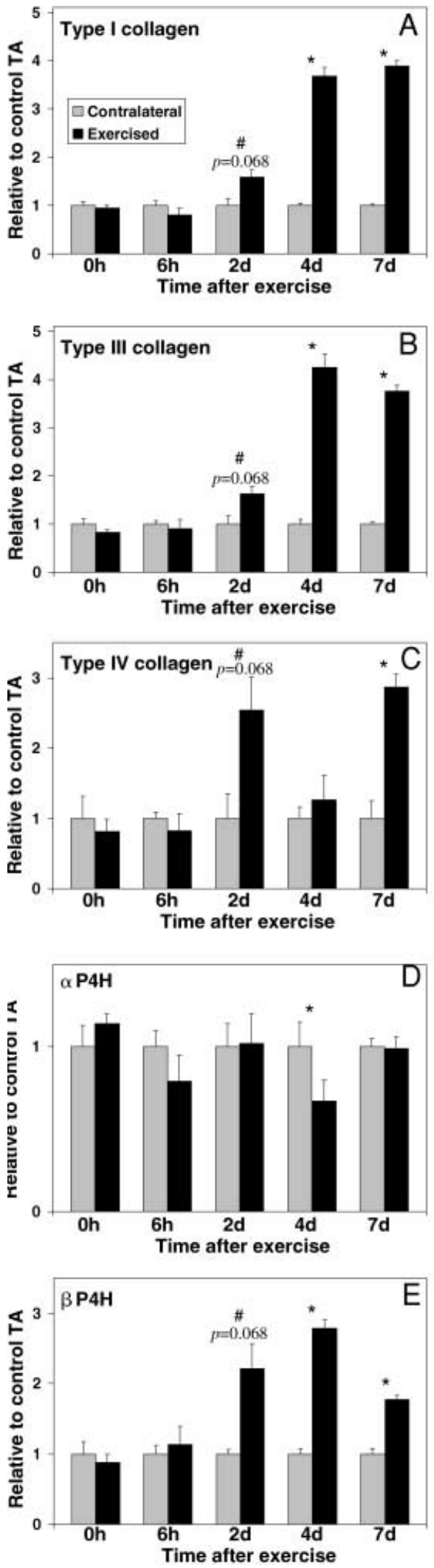
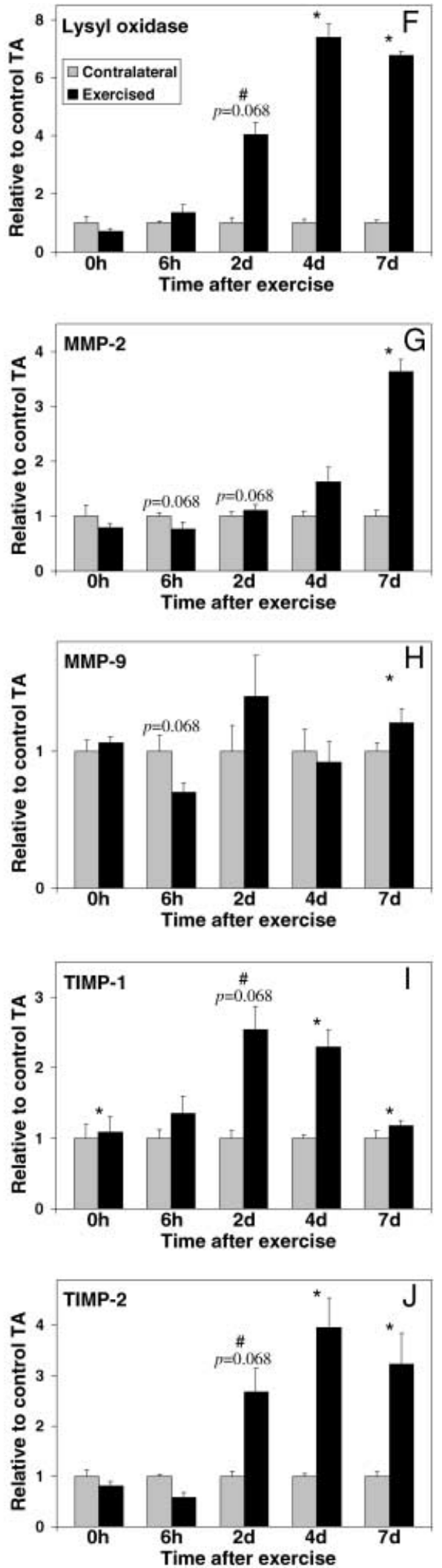


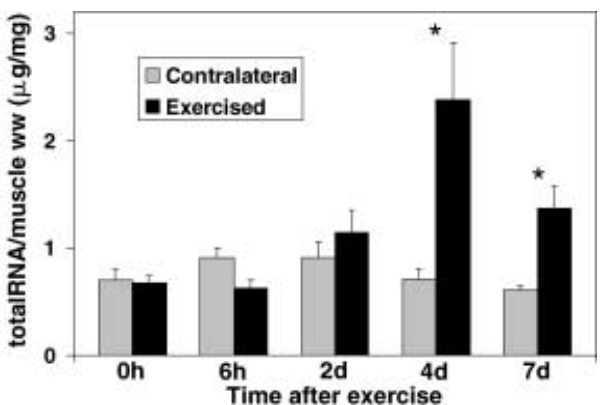

Fig. 10 The yield of total RNA per muscle wet weight. Values are means \pm SEM. ${ }^{*} P<0.05$ vs. contralateral TA

$\alpha$-subunit decreased 4 days postexercise (Fig. 9D). Somewhat in contrast, mRNA for the prolyl 4-hydroxylase $\beta$-subunit as well as that lysyl oxidase were higher than the contralateral TA level at 2, 4 and 7 days postexercise (Fig. 9E, F). Both mRNA levels for MMP-2 and MMP-9 showed a tendency to be lower in exercised TA than the contralateral one at $6 \mathrm{~h}($ Fig. 9G, H). This was followed by an increase resulting in higher values for both MMP-2 and MMP-9 in exercised TA compared to control muscle at 7 days postexercise. The increase in MMP-2 mRNA levels was more pronounced 7 days after forced lengthening contractions compared to MMP-9 mRNA. The mRNA levels for TIMP-1 and TIMP-2 were higher in the forced lengthened TA compared to the contralateral TA at 2, 4 and 7 days postexercise (Fig. 9I, J). TIMP-1 mRNA levels had a tendency to decrease from 2 days to 7 days after the contractions, while TIMP-2 levels were clearly elevated at 7 days postexercise.

\section{Discussion}

The present study indicates that forced lengthening contractions in rat TA muscle are accompanied by an activation of both type IV collagen synthesis and degradation for a period of at least 7 days postexercise. This is so, as mRNA for type IV collagen was doubled at 2 and 7 days and the content of type IV collagen elevated at 4 and 7 days after forced lengthening contractions. Furthermore, both mRNA and enzyme activities for the degrading metalloproteinases MMP-2 and MMP-9 were higher in the exercised TA than control at 4-7 days after exercise.

\section{Localization of types I, III, and IV collagen}

These findings provide further information regarding the processes accompanying the demonstrated disruption of the plasma membrane, the disorganized myofibrillar structure, fibre necrosis and inflammation [27]. In the present experimental model, muscle responded acutely (immediately after exercise) to forced lengthening by the presence of a few swollen fibres. The number of swollen fibres increased $6 \mathrm{~h}$ postexercise and some of these fibres were intracellularly fibronectin positive [27]. Immunostaining for different studied collagen types indicated the same staining pattern as in the contralateral TA muscle sections at two first observation points. Inflammation and fibre necrosis were advanced at 2 days and were clearly more pronounced at 4 days than at 2 days after the forced lengthening contractions [27]. In injured muscle fibres, which were dystrophin negative, intracellularly fibronectin positive and infiltrated by inflammatory cells, type IV collagen staining was still visible in the contour of the basement membranes of these fibres, as was endomysial staining for types I and III collagen. Clear signs of regeneration were observed 7 days after the forced lengthening contractions [27]. Type IV collagen staining was observed in the basement membranes of small central nucleated cells and a thin layer of endomysial staining for types I and III collagen was seen around these regenerating fibres. The results from light microscopy examination showed that types I, III and IV collagen were all located in swollen, necrotic and regenerated fibres, similarly as in undamaged skeletal muscle fibres. This is compatible with the view that the studied collagen types in skeletal muscle were present and could play an important role during the process of fibre damage when the cytoskeleton is disrupted [33], contractile proteins are disorganized [27] and extracellular fibronectin is deposited intracellularly [32].

\section{Collagen synthesis}

An increase in the activity of prolyl 4-hydroxylase 2, 4 and 7 days after forced lengthening contractions is indicative of overall elevated collagen biosynthesis, as prolyl 4-hydroxylase catalyses the first post-translational modification of collagen, resulting in the 4-hydroxylation of prolyl residues, and is required for proper formation of the triple helical form of procollagen [25]. The activity of prolyl 4-hydroxylase tended to be lower in exercised than in control muscle at $6 \mathrm{~h}$, but was increased at 2 days postexercise. This may indicate that stimulated muscle contractions result in a temporary lowering of synthesis, followed by a more prolonged stimulation of protein synthesis. Such a hypothesis is supported by findings in studies of connective tissue enzyme activity in rats [12], of collagen type I metabolism in peritendinous tissue [30] and of overall protein synthesis in muscle [42] in response to muscular contractions. On the other hand, prolyl 4-hydroxylase activity tended to be elevated in unexercised TA 6 h, 2, 4, and 7 days after forced lengthening contractions compared to the activity immediately after exercise. Chronic electrical stimulation of ankle flexors in the rat has been observed to decrease twitch tension in the contralateral muscles, probably through the release of systemic factors such as inorganic phosphate and various hormones [7]. It cannot be deduced from the present study whether the increase in prolyl 4-hydroxylase is due to systematic factors or neurotropic effects in the contra- 
lateral leg. The degree of muscle damage seems to affect prolyl 4-hydroxylase activity, and it was more severe but delayed in the present experiment compared with that in an experiment using downhill running $[12,38]$. In spite of a clear indication of increased collagen biosynthesis in the present study, there were no detectable changes in either total collagen concentration or in the type I to type III collagen ratio at any of the observation points. This is in line with earlier studies [12, 38]. Myllylä et al. [38] showed that muscle fibre damage in mice after acute downhill running caused the highest prolyl 4-hydroxylase activities at the same time as early regenerative changes were observed, whereas total collagen concentration did not increase until the regeneration process was complete. Similarly, in the present study the highest prolyl 4-hydroxylase activities were also observed at the same time as the first signs of regeneration. It cannot be excluded that the observations made 7 days after forced lengthening contractions were too early to detect any changes in insoluble collagen concentration, because of its relatively slow turnover rate and the possibility that a proportion of the newly synthesized collagen is degraded without being deposited [35]. Although there were no changes in the total collagen concentration, the type IV collagen concentration increased clearly 4 and 7 days postexercise. This can be explained by the fact that type IV collagen contributes only a small portion of the total collagen concentration in skeletal muscle, thus making it difficult to result in overall net collagen synthesis. In one of our earlier experiments [28], using downhill running as an intervention, the type IV collagen concentration decreased in the red part of rat quadriceps femoris muscle, but not in other parts of the muscle or in soleus muscle. Interestingly, the red part of quadriceps femoris muscle was the most damaged muscle in that study. The difference in the behaviour of type IV collagen concentration in these two experiments can be explained by more severe muscle damage and longer degeneration and regeneration processes occurring in skeletal muscle after forced lengthening contractions than after total body exercise.

\section{Degradation of collagen}

In this study, MMP-2 and MMP-9 were upregulated with differential patterns related to the time course of muscle necrosis and regeneration. This finding is somewhat different from those in previous downhill running experiments, in which no signs of MMP-9 activity were observed [28]. Following skeletal muscle damage induced by cardiotoxin injection, Kherif et al. [21] showed that MMP-9 is involved in tissue remodelling during the early inflammatory phase, whereas MMP-2 is related to the prolonged remodelling phase. The results from the present study together with our earlier study [28] suggest that the presence of MMP-9 in exercise-induced muscle damage depends on the severity of skeletal muscle fibre injury. The mechanism behind the activation of MMPs in tis- sue remodelling has been shown to be tightly regulated by growth factors and cytokines (reviewed in [2]). In vitro experiments have shown that prostaglandin stimulates MMP-2 and MMP-9 expression in human T cells [8]. Although the release of prostaglandin was not determined in the present study, the observations from microscopy examinations clearly show that forced lengthening causes the infiltration of inflammatory cells into the skeletal muscle. Furthermore, the release of prostaglandins has been demonstrated both in human muscle during intense contractions [19] as well as in peritendineous tissue [30] by the use of microdialysis. An important step in the regulation of MMP activity is its conversion from the latent to the active form by proteolytic removal of the propeptide. Collagenase activity of proMMP-9 was elevated in a few samples as early as $6 \mathrm{~h}$ after forced lengthening contractions. At this point only a few skeletal muscle fibres were intracellularly fibronectin positive. When inflammation was advanced 2 days postexercise, proMMP-2 and proMMP-9 activities were both enhanced. Active forms of MMP-2 and MMP-9 together with increased levels of proMMP-2 and proMMP-9 were observed 4 days postexercise when the inflammation reaction was most pronounced. At the latest observation point in the present study, 7 days after forced lengthening contractions when clear sings of regeneration was observed, proMMP-9 and the active form of MMP-9 were only faintly visible, while both proMMP-2 and the active form of MMP-2 were still elevated. Although MMP-2 and MMP-9 have a nearly identical digestion profile against extracellular matrix compounds [51], their expression seems to depend on the stage of the degeneration and regeneration process in rat skeletal muscle.

\section{Inhibition of collagen degradation}

MMP-2-inhibitory activity of TIMP-2 was elevated at the same time as the gelatinolytic activity of MMP-2. This is accordance with our previous study [28], in which MMP-2 and TIMP-2 levels seemed to increase and decrease at the same time, at both the mRNA and the protein level, in the damaged red part of the quadriceps femoris muscle. The recent results suggest that TIMP-2 is required for the efficient activation of proMMP-2 in vivo [3, 49], even though overall TIMP-2 inhibits MMP2 activity in a membrane-type MMP-dependent process, in which TIMP-2 regulates the proteolytic activation of proMMP-2 at the cell surface. In the present study the MMP-2-inhibitory activity of TIMP-1 remained undetectable in all of the samples studied. TIMP-1 and TIMP2 are reported to perform different functions in vivo [50]. In running-induced skeletal muscle damage, TIMP-1 was found to be activated during the early phase of muscle damage, whereas TIMP-2 is upregulated during the later phase of muscle damage [28]. Although the role of TIMPs is clearly important in inhibiting matrix degradation by MMPs, according to cell culture studies it seems 
that TIMP-1 and TIMP-2 have other functions such as growth factor activity [14, 15], an effect on cell morphology [41], and inhibition of angiogenesis [17]; however, the exact role of their upregulation in response to intensive eccentric exercise cannot be stated from the present study.

\section{Total RNA concentration}

Two- to threefold increases in total RNA concentrations were found 4 and 7 days after forced lengthening contractions. This is probably due to the increased numbers of cells, such as inflammatory cells and differentiated satellite cells, in exercised skeletal muscles. Correspondingly, a similar increase in total RNA concentrations was observed in response to increased muscle loading in muscles undergoing compensatory hypertrophy, and it appears to be related to the differentiation of a specific population of cells in the target muscle [1]. In the present study the different cell types were not identified, but Komulainen et al. [27] suggested that several cell types are activated in exercised muscles, e.g. satellite cells, fibroblasts, endothelial cells and inflammatory cells.

\section{Expression of specific mRNA levels}

The steady-state mRNA levels for types I and III collagen indicated that there was a lower relative increase in the present experiment than in our previous downhill running experiment [28]. This was somewhat unexpected, since our previous study suggested that greater muscle damage corresponds with a greater relative increase in fibrillar type collagen levels [12, 28]. Interestingly, there were no increases in type IV collagen mRNA levels $6 \mathrm{~h}$ after forced lengthening contractions, whereas in our downhill running experiment the levels were elevated $6 \mathrm{~h}$ postexercise regardless of the magnitude of muscle damage [28].

Elevated mRNA levels for the $\beta$-subunit of prolyl 4hydroxylase and lysyl oxidase, the posttranslational enzymes of collagen synthesis, were observed 2, 4, and 7 days postexercise. Unchanged or decreased mRNA levels were measured for the $\alpha$-subunit of prolyl 4-hydroxylase, but the levels were increased in unexercised TA $6 \mathrm{~h}, 2$ and 4 days postexercise compared to unexercised TA (observation made immediately after the experiment, data not shown). The present findings, namely that both the activity of prolyl 4-hydroxylase and the mRNA level for the $\alpha$-subunit of prolyl 4-hydroxylase increased, are in line with previous studies $[12,52]$. It has been suggested that the amount of the active prolyl 4-hydroxylase tetramer $\left(\alpha_{2} \beta_{2}\right)$ is regulated through the amount of the $\alpha$-subunit [24]. The relative increase in mRNA for lysyl oxidase was also lower in the present study than in the downhill running experiment [12]. This extracellular posttranslational enzyme plays an important role in the control of insoluble collagen accumulation, by catalysing the oxidative deamination of lysine residues in collagen [46]. Increased lysyl oxidase activities have been shown to be associated with fibrotic disorders [46]. The differences in the behaviour of mRNA levels for the collagen types studied and the post-translational modificators between these two experiments are probably caused by more severe and delayed muscle damage in the present study compared to the previous study. According to in vitro studies, macrophages may play a role in delayed muscle damage by enhancing muscle satellite cell proliferation and delaying their differentiation [36]. It is not very well documented which cell types produce the studied collagen types or the post-translational modificators in vivo in skeletal muscle. However, it has been shown that types I, III and IV collagen are produced in vitro by muscle cells and by fibroblasts [29, 44], but it is not known at which stage of differentiation these cell types are capable of producing the collagen types studied and whether inflammatory cells produce collagens at all. Variation in the relative proportions of the different cell populations with the stages of skeletal fibre injury may appear to decrease the mRNA levels studied. For example, to the unexpected decrease in type IV collagen mRNA level 4 days after forced lengthening contractions could be due to an increase in the number of cells that cannot produce type IV collagen.

A clear increase in mRNA for MMP-2 was observed when the signs of regeneration were seen, i.e. 7 days postexercise. A wide range of cell types, e.g. connective tissue cells and human myogenic cells [11], has been shown to produce and secrete MMP-2, whereas its expression in vivo in skeletal muscle has not been documented. Kherif et al. [21] showed by in situ hybridization that MMP-9 is localized in inflammatory cells identified as polymorphonuclear leucocytes and macrophages, and in mononucleated cells at the periphery of injured myofibres. In the present study there was no clear trend in the mRNA levels of MMP-9, probably because of the increased mRNA levels in unexercised TA $6 \mathrm{~h}, 2$ and 4 days postexercise compared to unexercised TA observed immediately after the experiment (data not shown). TIMP-1 and TIMP-2 responded differently to muscle damage: mRNA levels for TIMP-1 tended to decrease while mRNA levels for TIMP-2 were elevated. Interestingly, TIMPs are secreted by the same cell types as MMP-2 and MMP-9 [10], but their expression in vivo in skeletal muscle is not known at the moment.

In conclusion, the present study indicates that acute damaging exercise results in an increased type IV collagen content over the following 7 days in rat TA muscle. This increase in the net synthesis of type IV collagen is the result of both increased synthesis and the activation of degrading enzymes and their inhibitors. 
Acknowledgements The present study was supported by the Finnish Ministry of Education, and the Finnish Graduate School in Musculo-Skeletal Problems. The authors thank Mrs. M. Koistinen, Mrs. A. Ollikainen and Mrs. T. Nykänen for excellent technical assistance in biochemical and molecular biological analysis. Dr. K. Kivirikko (Department of Medical Biochemistry, University of Oulu, Finland) generously provided recombinant human type III collagen. The recombinant plasmids were kindly provided by Dr. K. Tryggvason (Department of Medical Biochemistry and Biophysics, Karolinska Institute, Stockholm, Sweden), Dr. M. Kurkinen (Wayne State University School of Medicine, Center for Molecular Medicine and Genetics, Detroit, USA), Dr. E. Vuorio (Department of Molecular Biology, University of Turku, Finland), Dr PC Trackman (Department of Periodontology and Oral Biology, Boston University Goldman School of Dental Medicine, USA) and Dr. T. Helaakoski (Department of Medical Biochemistry, University of Oulu, Finland). The antibody against the $7 \mathrm{~S}$ domain of mouse type IV collagen and labelled $7 \mathrm{~S}$ antigen was generous gifts from Dr. J. Risteli (Department of Clinical Chemistry, University of Oulu, Oulu, Finland). Rabbit polyclonal anti-fibronectin generously provided by Dr. Matti Vuento (Department of Biochemistry, University of Jyväskylä, Finland).

\section{References}

1. Adams GR, Haddad F, Baldwin KM (1999) Time course of changes in markers of myogenesis in overloaded rat skeletal muscles. J Appl Physiol 87:1705-1712

2. Birkedal-Hansen H, Moore WG, Bodden MK, Windsor LJ, Birkedal-Hansen B, DeCarlo A, Engler JA (1993) Matrix metalloproteinases: a review. Crit Rev Oral Biol Med 4:197-250

3. Caterina JJ, Yamada S, Caterina NCM, Longenecker G, Holmback K, Shi J, Yermovsky AE, Engler JA, Birkedal-Hansen H (2000) Inactivating mutation of the mouse tissue inhibitor of metalloproteinases-2 (TIMP-2) gene alters proMMP-2 activation. J Biol Chem 275:26416-26422

4. Chan YL, Gutell R, Noller HF, Wool IG (1984) The nucleotide sequence of a rat $18 \mathrm{~S}$ ribosomal ribonucleic acid gene and a proposal for the secondary structure of $18 \mathrm{~S}$ ribosomal ribonucleic acid. J Biol Chem 259:224-230

5. Chiquet M (1999) Regulation of extracellular matrix gene expression by mechanical stress. Matrix Biol 18:417-426

6. Creemers LB, Jansen DC, van Veen-Reurings A, van den Bos T, Everts V (1997) Microassay for the assessment of low levels of hydroxyproline. Biotechniques 22:656-658

7. Egginton S, Hudlická O (1999) Early changes in performance, blood flow and capillary fine structure in rat fast muscles induced by electrical stimulation. J Physiol (Lond) 515:265-275

8. Goetzl EJ, Banda MJ, Leppert D (1996) Matrix metalloproteinases in immunity. J Immunol 156:1-4

9. Gogly B, Groult N, Hornebeck W, Godeau G, Pellat B (1998) Collagen zymography as a sensitive and specific technique for the determination of subpicogram levels of interstitial collagenase. Anal Biochem 255:211-216

10. Gomez DE, Alonso DF, Yoshiji H, Thorgeirsson UP (1997) Tissue inhibitors of metalloproteinases: structure, regulation and biological functions. Eur J Cell Biol 74:111-122

11. Guerin CW, Holland PC (1995) Synthesis and secretion of matrix-degrading metalloproteases by human skeletal muscle satellite cells. Dev Dyn 202:91-99

12. Han XY, Wang W, Komulainen J, Koskinen SOA, Kovanen V, Vihko V, Trackman PC, Takala TES (1999) Increased mRNAs for procollagens and key regulating enzymes in rat skeletal muscle following downhill running. Pflugers Arch 437:857864

13. Hanson AN, Bentley JP (1983) Quantitation of type I to type III collagen ratios in small samples of human tendon, blood vessels, and atherosclerotic plaque. Anal Biochem 130:32-40

14. Hayakawa T, Yamashita K, Ohuchi E, Shinagawa A (1994) Cell-growth-promoting activity of tissue inhibitor of metalloproteinase-2 (TIMP-2). J Cell Sci 107:2373-2379
15. Hayakawa T, Yamashita K, Tanzawa K, Uchijima E, Iwata K (1992) Cell-growth-promoting activity of tissue inhibitor of metalloproteinase-1 (TIMP-1) for wide range of cells. FEBS Lett 298:29-32

16. Hesselink MK, Kuipers H, Geurten P, Van Straaten H (1996) Structural muscle damage and muscle strength after incremental number of isometric and forced lengthening contractions. J Muscle Res Cell Motil 17:335-341

17. Johnson MD, Kim HRC, Chesler L, Tsao-Wu G, Bouck N, Polverini PJ (1994) Inhibition of angiogenesis by tissue inhibitor of metalloproteinase. J Cell Physiol 160:194-202

18. Juva K, Prockop DJ (1966) Modified procedure for the assay of H3- or C14-labeled hydroxyproline. Anal Biochem 15:7783

19. Karamouzis M, Langberg, H, Skovgaard D, Bülow J, Kjær M, Saltin B (2001) In situ microdialysis of intramuscular prostaglandin and thromboxane in contracting skeletal muscle in humans. Acta Physiol Scand 171:71-76

20. Karttunen T, Risteli J, Autio-Harmainen H, Risteli L (1986) Effect of age and diabetes on type IV collagen and laminin in human kidney cortex. Kidney Int 30:586-591

21. Kherif S, Lafuma C, Dehaupas M, Lachkar S, Fournier JG, Verdiere-Sahuque M, Fardeau M, Alameddine HS (1999) Expression of matrix metalloproteinases 2 and 9 in regenerating skeletal muscle: a study in experimentally injured and $\mathrm{mdx}$ muscles. Dev Biol 205:158-170

22. Kivirikko KI, Helaakoski T, Tasanen K, Vuori K, Myllylä R, Parkkonen T, Pihlajaniemi T (1990) Molecular biology of prolyl 4-hydroxylase. Ann NY Acad Sci 580:132-142

23. Kivirikko KI, Myllylä R (1982) Posttranslational enzymes in the biosynthesis of collagen: intracellular enzymes. Methods Enzymol 82:245-304

24. Kivirikko KI, Myllylä R, Pihlajaniemi T (1989) Protein hydroxylation: prolyl 4-hydroxylase, an enzyme with four cosubstrates and a multifunctional subunit. FASEB J 3:1609-1617

25. Kivirikko KI, Myllylä R, Pihlajaniemi T (1992) Hydroxylation of proline and lysine residues in collagens and other animal and plant proteins. In: Harding JJ, Crabbe MJC (eds) Posttranslational modifications of proteins. CRC, Boca Raton, Fla. pp 1-51

26. Kleiner DE, Stetler-Stevenson WG (1994) Quantitative zymography: detection of picogram quantities of gelatinases. Anal Biochem 218:325-329

27. Komulainen J, Takala TES, Kuipers H, Hesselink MK (1998) The disruption of myofibre structures in rat skeletal muscle after forced lengthening contractions. Pflugers Arch 436:735741

28. Koskinen SOA, Wang W, Ahtikoski AM, Kjær M, Han XY, Komulainen J, Kovanen V, Takala TES (2001) Acute exercise induced changes in rat skeletal muscle mRNAs and proteins regulating type IV collagen content. Am J Physiol 280: R1292-R1300

29. Kühl U, Timpl R, von der Mark K (1982) Synthesis of type IV collagen and laminin in cultures of skeletal muscle cells and their assembly on the surface of myotubes. Dev Biol 93: 344-354

30. Langberg H, Skovgaard D, Petersen LJ, Bulow J, Kjaer M (1999) Type I collagen synthesis and degradation in peritendinous tissue after exercise determined by microdialysis in humans. J Physiol (Lond) 521:299-306

31. Laurent GJ, Cockerill P, McAnulty RJ, Hastings JR (1981) A simplified method for quantitation of the relative amounts of type I and type III collagen in small tissue samples. Anal Biochem 113:301-312

32. Lieber RL, Schmitz MC, Mishra DK, Fridén J (1994) Contractile and cellular remodeling in rabbit skeletal muscle after cyclic eccentric contractions. J Appl Physiol 77:1926-1934

33. Lieber RL, Thornell LE, Fridén J (1996) Muscle cytoskeletal disruption occurs within the first $15 \mathrm{~min}$ of cyclic eccentric contraction. J Appl Physiol 80:278-284

34. Light ND (1982) Estimation of types I and III collagens in whole tissue by quantitation of $\mathrm{CNBr}$ peptides on SDS-polyacrylamide gels. Biochim Biophys Acta 702:30-36 
35. McAnulty RJ, Laurent GJ (1987) Collagen synthesis and degradation in vivo. Evidence for rapid rates of collagen turnover with extensive degradation of newly synthesized collagen in tissues of the adult rat. Coll Relat Res 7:93-104

36. Merly F, Lescaudron L, Rouaud T, Crossin F, Gardahaut MF (1999) Macrophages enhance muscle satellite cell proliferation and delay their differentiation. Muscle Nerve 22:724-732

37. Myllylä R, Myllylä VV, Tolonen U, Kivirikko KI (1982) Changes in collagen metabolism in diseased muscle. I. Biochemical studies. Arch Neurol 39:752-755

38. Myllylä R, Salminen A, Peltonen L, Takala TE, Vihko V (1986) Collagen metabolism of mouse skeletal muscle during the repair of exercise injuries. Pflugers Arch 407:64-70

39. Nagase H, Woessner JF Jr (1999) Matrix metalloproteinases. J Biol Chem 274:21491-21494

40. Oliver GW, Leferson JD, Stetler-Stevenson WG, Kleiner DE (1997) Quantitative reverse zymography: analysis of picogram amounts of metalloproteinase inhibitors using gelatinase A and B reverse zymograms. Anal Biochem 244: 161-166

41. Ray JM, Stetler-Stevenson WG (1995) Gelatinase A activity directly modulates melanoma cell adhesion and spreading. EMBO J 14:908-917

42. Rennie MJ, Tipton KD (2000) Protein and amino acid metabolism during and after exercise and the effects of nutrition. Annu Rev Nutr 20:457-483

43. Risteli J, Rohde H, Timpl R (1981) Sensitive radioimmunoassays for $7 \mathrm{~S}$ collagen and laminin: application to serum and tissue studies of basement membranes. Anal Biochem 113: 272-278

44. Sasse J, von der Mark H, Kühl U, Dessau W, von der Mark K (1981) Origin of collagen types I, III, and V in cultures of avian skeletal muscle. Dev Biol 83:79-89
45. Savolainen J, Väänänen K, Vihko V, Puranen J, Takala TES (1987) Effect of immobilization on collagen synthesis in rat skeletal muscles. Am J Physiol 252:R883-R888

46. Smith-Mungo LI, Kagan HM (1998) Lysyl oxidase: properties, regulation and multiple functions in biology. Matrix Biol 16:387-398

47. Takala TES, Myllylä R, Salminen A, Anttinen H, Vihko $\mathrm{V}(1983)$ Increased activities of prolyl 4-hydroxylase and galactosylhydroxylysyl glucosyltransferase, enzymes of collagen biosynthesis, in skeletal muscle of endurance-trained mice. Pflugers Arch 399:271-274

48. Turto H, Lindy S, Halme J (1974) Protocollagen proline hydroxylase activity in work-induced hypertrophy of rat muscle. Am J Physiol 226:63-65

49. Wang Z, Juttermann R, Soloway PD (2000) TIMP-2 is required for efficient activation of proMMP-2 in vivo. $\mathrm{J}$ Biol Chem 275:26411-26415

50. Wang Z, Soloway PD (1999) TIMP-1 and TIMP-2 perform different functions in vivo. Ann NY Acad Sci 878:519-521

51. Woessner JF Jr (1991) Matrix metalloproteinases and their inhibitors in connective tissue remodeling. FASEB J 5:21452154

52. Yeowell HN, Murad S, Pinnell SR (1991) Hydralazine differentially increases mRNAs for the alpha and beta subunits of prolyl 4-hydroxylase whereas it decreases pro alpha 1(I) collagen mRNAs in human skin fibroblasts. Arch Biochem Biophys 289:399-404

53. Yurchenco PD, Schittny JC (1990) Molecular architecture of basement membranes. FASEB J 4:1577-1590 